\title{
Comparison of the changes of alveolar bone thickness in maxillary incisor area in extraction and non-extraction cases: Computerized tomography evaluation
}

\author{
Paulo Roberto Barroso Picanço1, Fabricio Pinelli Valarelli², Rodrigo Hermont Cançado², \\ Karina Maria Salvatore de Freitas ${ }^{3}$, Gracemia Vasconcelos Picanço
}

\begin{abstract}
Objective: To compare, through computed tomography, alveolar bone thickness changes at the maxillary incisors area during orthodontic treatment with and without tooth extraction. Methods: Twelve patients were evaluated. They were divided into 2 groups: G1 - 6 patients treated with extraction of right and left maxillary first premolars, with mean initial age of 15.83 years and mean treatment length of 2.53 years; G2 - 6 patients treated without extraction, with mean initial age of 18.26 years and mean treatment length of 2.39 years. Computed tomographies, lateral cephalograms and periapical radiographs were used at the beginning of the treatment $\left(\mathrm{T}_{1}\right)$ and 18 months after the treatment had started $\left(\mathrm{T}_{2}\right)$. Extraction space closure occurred in the extraction cases. Intragroup and intergroup comparisons were performed by dependent and independent $t$ test, respectively. Results: In G1, the central incisor was retracted and uprighted, while in G2 this tooth showed vestibularization. Additionally, G1 presented a higher increase of labial alveolar bone thickness at the cervical third in comparison with G2. The incidence of root resorption did not present significant differences between groups. Conclusion: There were no changes in alveolar bone thickness when extraction and nonextraction cases were compared, except for the labial alveolar bone thickness at the cervical third of maxillary incisors.
\end{abstract}

Keywords: Alveolar ridge. Tooth movement. Tooth extraction. Tomography.

Objetivo: comparar, por meio de tomografia computadorizada, a alteração da espessura óssea alveolar na região de incisivos superiores durante o tratamento ortodôntico, com e sem extração dentária. Métodos: foram avaliados 12 pacientes, divididos em dois grupos: G1, seis pacientes tratados com extrações de dois primeiros pré-molares superiores, com idade média inicial de 15,83 anos, e tratados por um tempo médio de 2,53 anos; G2, seis pacientes tratados sem extrações, com idade média inicial de 18,26 anos e tratados por um período de 2,39 anos. Foram utilizadas tomografias computadorizadas, telerradiografias em norma lateral e radiografias periapicais ao início $\left(\mathrm{T}_{1}\right)$ e após 18 meses de tratamento $\left(\mathrm{T}_{2}\right)$, desde que o espaço da extração já estivesse fechado nos casos tratados com extrações. A comparação intragrupo foi realizada por meio do teste $t$ dependente, e a comparação intergrupos por meio do com o teste $t$ independente. Resultados: o grupo 1 apresentou uma retração e verticalização do incisivo central, enquanto o grupo 2 apresentou uma vestibularização desse dente. Além disso, o grupo 1 apresentou maior aumento da espessura óssea cervical vestibular durante o tratamento, quando comparado ao grupo 2. A incidência de reabsorção radicular não apresentou diferenças significativas entre os grupos. Conclusões: não houve alteração nas espessuras ósseas alveolares quando comparados casos tratados com e sem extrações, com exceção da espessura óssea vestibular na região cervical dos incisivos superiores.

Palavras-chave: Processo alveolar. Movimentação dentária. Extração dentária. Tomografia.

${ }^{1} \mathrm{MSc}$ in Orthodontics, Uningá. Professor, Paulo Picanço Center of Orthodontics.

${ }^{2}$ Adjunct Professor, Uningá.

${ }^{3}$ Post-Doc in Orthodontics, University of Toronto. Professora, Uningá.

" The authors report no commercial, proprietary or financial interest in the products or companies described in this article.
How to cite this article: Picanço PRB, Valarelli FP, Cançado RH, Freitas KMS, Picanço GV. Comparison of the changes of alveolar bone thickness in maxillary incisor area in extraction and non-extraction cases: Computerized tomography evaluation. Dental Press J Orthod. 2013 Sept-Oct;18(5):91-8.

Submitted: October 21, 2010 - Revised and accepted: October 22, 2011

Contact address: Fabrício Valarelli

Rua Manoel Pereira Rolla, 12-75, apto 503 - Bauru/SP - CEP: 17012-190

E-mail: fabriciovalarelli@uol.com.br 


\section{INTRODUCTION}

Orthodontic movement can be quick or slow, depending on the physical characteristics of the applied force, the size and the biological response of the periodontal ligament. ${ }^{1}$ According to Vardimon, Oren and Ben-Bassat, ${ }^{2}$ there is an axiom in orthodontics that says: "tooth movement leaves marks on the bone", however, this fact is not always favorable. In vertical direction, during tooth extrusion, the changes in the underlying bone tissue may not follow tooth displacement, leading to an increase in clinical length of the tooth crown, oftentimes undesirable. In transverse and anteroposterior directions, bone dehiscence and fenestration have been reported when the incisors are either protruded or retracted. ${ }^{3,4}$ According to Handelman, ${ }^{5}$ labial and lingual/ palatal bone cortical plates at incisors' apexes may represent anatomical limits to orthodontic tooth movement. The literature has speculated that protrusion and vestibularization of the maxillary incisors may produce labial bone cortical dehiscence while teeth retraction affects the palatal bone plate, although this would be reversible only if the teeth returned to their original position. ${ }^{6}$

Designing the limits of tooth movement before beginning the orthodontic treatment may be extremely beneficial, especially in situations in which skeletal discrepancy is severe or the maxilla and/or mandible can accommodate, in a limited way, the repositioning of the teeth after orthodontic movement. ${ }^{5,7}$

To detect bone levels, the following methods may be used: periapical radiographs, lateral cephalograms and panoramic radiographs. Notwithstanding, bidimensional radiographs reveal some limitations, such as image superimposition and distortions as well as the inability of measuring bone thickness in panoramic and periapical radiographs. ${ }^{7,8}$ Taking these factors into account, computed tomography (CT) has been considered of paramount importance for diagnosing initial bone levels as well as bone level changes during orthodontic treatment. ${ }^{9,10}$

The aim of this study was to compare, through computed tomography, the alveolar bone thickness changes at the maxillary incisors area during orthodontic treatment with or without maxillary premolar extractions.

\section{MATERIAL AND METHODS}

\section{Sample}

Twelve patients of both genders were selected in the orthodontic clinic Paulo Picanço. Inclusion criteria were: 1) permanent dentition; 2) absence of systemic disease that may alter bone metabolism; 3) nonsmoker; 4) patients who are not using steroid-based drugs; 5) absence of chronic kidney disease; 6) if female, patients who do not present low level of estrogen; 7) presence of all six maxillary anterior teeth; 8) patients who have not undergone tooth trauma, alveolar bone fracture or luxation in maxillary incisors; 9) patients who do not present a prosthetic crown on maxillary incisors; 10) absence of alveolar cleft in the maxillary anterior area.

The sample was divided into two groups: G1 - 6 patients (5 male; 1 female) with mean initial age of $15.83 \pm 4.87$ years, presenting Class II malocclusion, treated with 2 maxillary premolar extractions during a mean period of $2.53 \pm 0.49$ years; $\mathrm{G} 2-6$ patients ( 5 male; 1 female), with mean initial age of $18.26 \pm 6.42$ years, 3 showing Class I and 3 Class II malocclusion, treated without extractions during a mean treatment period of $2.39 \pm 0.66$ years.

Patients were treated by post-graduation students oriented by the same professor, following the same diagnosis pattern, treatment planning and orthodontic mechanics (Edgewise, 0.018 x 0.025-in brackets - Morelli - Sorocaba, SP, Brazil).

\section{Methods}

Computed tomographies were performed at the beginning of the orthodontic treatment $\left(\mathrm{T}_{1}\right)$ and 18 months after the treatment had started, $\left(\mathrm{T}_{2}\right)$. The exams confirmed extraction space closure. Additionally, periapical radiographs were performed at $T_{1}$ and $\mathrm{T}_{2}$ using the parallelism technique in order to evaluate external root resorption of the maxillary incisors. Lateral cephalograms were performed to evaluate anteroposterior and vertical changes as well as the inclination of these teeth.

For cephalograms and tomographs evaluation, image digitalization and measurement processing, Dolphin Imaging Premium 10.5 software (Dolphin Imaging \& Management Solutions, Chatsworth, CA, USA) was used.

UL (labial) and UP (palatal) variables were obtained from the long axis of the maxillary incisor and a point of reference (zero point) marked at the enamelcementum junction (ECJ). From this point of reference, three lines were traced towards apical direction, with a $3 \mathrm{~mm}$ interval, up to the most external limit of the labial (UL) and palatal (UP) alveolar bone, perpendicularly to the tooth long axis (Fig 1). 
On the lateral cephalograms, the following variables were analyzed: 1-PTV incisal, 1-PTV apical, FMA, PFH/AFH, Wits, 1.NA, H-11 and UL+UP.

The degree on initial and final root resorption was analysed through periapical radiographs, based on the scores of Levander and Malmgren's score system: ${ }^{11} 0$ - lack of root resorption; 1 - presence of apical irregularities; 2 - presence of root resorption up to $2 \mathrm{~mm} ; 3$ - presence of root resorption from $2 \mathrm{~mm}$ to one third of the root original length; 4 - presence of root resorption greater than one third of the original length of the root. Root length was obtained from measuring the distance from root apex to ECJ, following the incisor long axis (Fig 2).

\section{Method error}

To determine intraexaminer error, both lateral cephalograms and tomographies were reevaluated in 6 randomly selected patients after a month interval. Systematic error was determined by dependent $t$ test while casual error was determined by the Dahlberg's formula. Kappa test was used to establish root resorption score error.

\section{Statistical analysis}

The following statistical tests were employed: difference between two means for carrying out the sample calculation, chi-square test for intergroup comparison

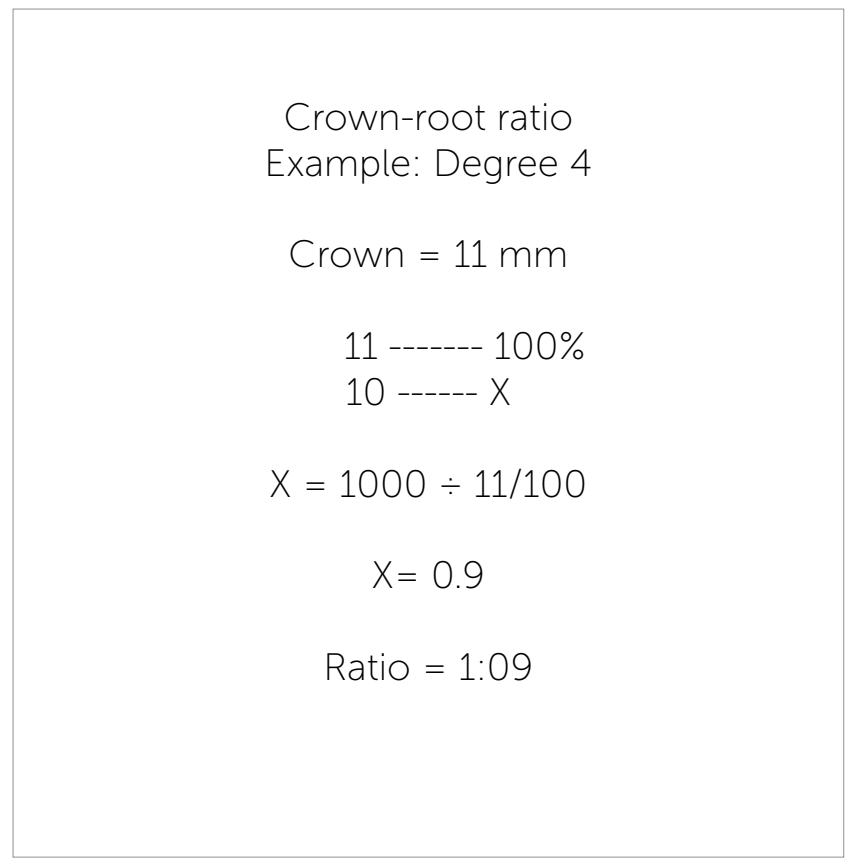

Figure 2 - Crown-root ratio and maxillary central incisor length assessment concerning the malocclusion type; independent $\mathrm{t}$ test for intergroup age and treatment period comparison; dependent $t$ test for intragroup initial and final stages comparison; independent $t$ test for intergroup initial and final stages as well as treatment changes comparison. All tests were performed with Statistica software (Statistica for Windows, version 7.0, Statsoft, 2005). The results were considered significant at $\mathrm{p}<0.05$.

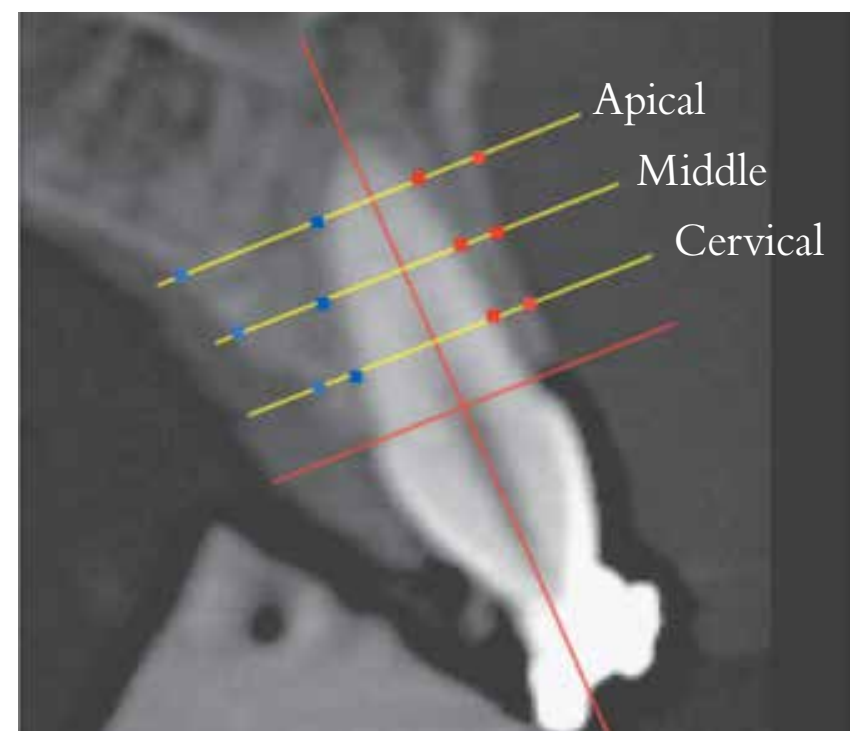

Figure 1 - Alveolar bone thickness assessment evaluated through computed tomography.

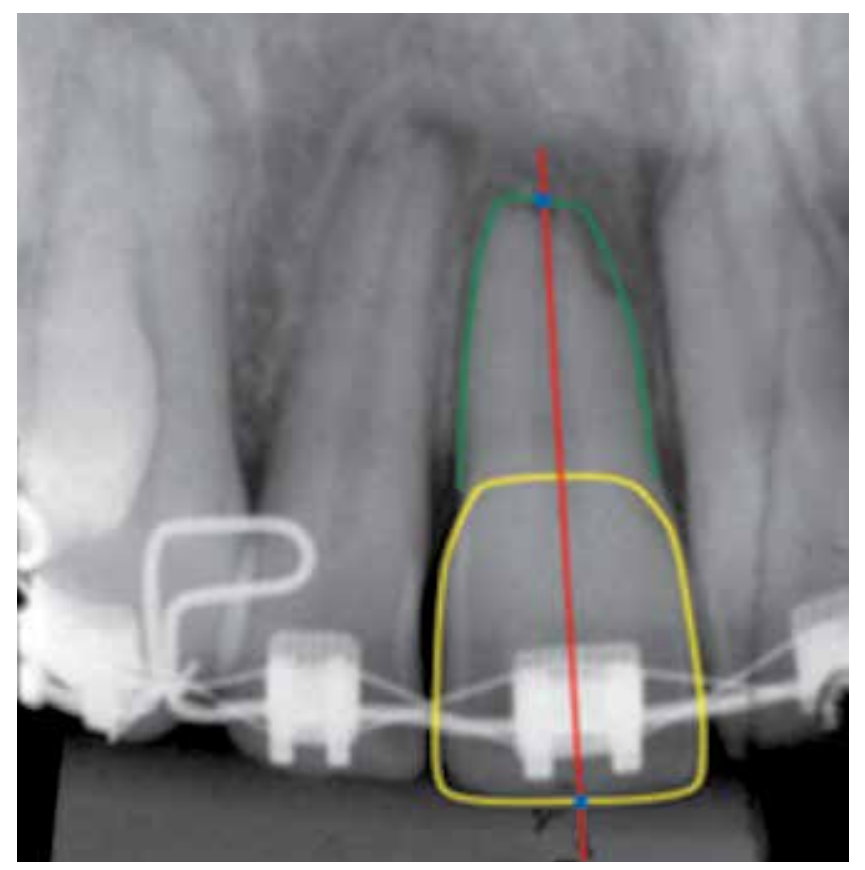




\section{RESULTS}

The 1-PTV apical variable showed the greatest casual error $(1.57 \mathrm{~mm})$. Systematic error occurred only for the following variables: 1-PTV incisal and UP middle. Kappa coefficient demonstrated a concordance percentage of $90 \%$.

There were differences in the distribution of the malocclusion type between groups (Table 1). The groups were compatible regarding gender, initial and final ages as well as treatment period (Table 2).

At the initial stage $\left(\mathrm{T}_{1}\right)$, only 1-PTV apical showed statistically significant difference between groups, indicating that in G1 the maxillary incisor was more protruded than in G2 (Table 3).

The comparison between G1 (treated with two maxillary premolar extractions) stages $\left(T_{1}\right.$ and $\left.T_{2}\right)$ demonstrated that there was a decrease in the crown-root ratio and in the central incisor length, a retraction of these teeth both in apical (1-PTV apical) and incisal (1-PTV incisal) measurements, a decrease in anteroposterior discrepancy (ANB), an increase of the UL cervical (labial cervical third) measurement and decrease of the UP cervical (palatal cervical third) and UP middle (palatal middle third) measurements (Table 4).

In G2 (treated without extractions), the comparison between $T_{1}$ and $T_{2}$ demonstrated that there was a decrease in the crown-root ratio, in the central incisor length, in FMA angle, in the relation between posterior and anterior face height, vestibularization of the maxillary incisors (1.NA) and a decrease in the UP middle measurement as well (Table 5).

At $T_{2}$, there was statistically significant difference between the groups in two variables: 1-PTV incisal and UL cervical. The difference in 1-PTV incisal indicated that, at the end of the treatment, central incisors in G1 were more retruded than in G2 while the difference in UL cervical showed higher bone thickness at this area in G1 than in G2 (Table 6).

With regard to treatment changes $\left(\mathrm{T}_{2}-\mathrm{T}_{1}\right)$, the 1-PTV incisal, 1-PTV apical and 1.NA measurements were statistically significant different between groups, revealing that G1 showed maxillary incisor's retraction and uprighting while G2 exhibited this tooth protrusion and vestibularization (Table 7). Additionally, UL cervical measurement was also significantly different between groups indicating an increase of labial bone thickness in G1 when compared to G2 (Table 7).
With regard to root resorption degree, there were no significant differences between groups at any of the evaluated periods (Table 8 ).

\section{DISCUSSION}

Handelman ${ }^{5}$ claims that a thin tooth alveolus or an inappropriate alveolar cavity for the amount of desirable tooth movement must be considered as a risk for

\begin{tabular}{cccc} 
Table 1 - Intergroup comparison of malocclusion type (chi-square test). \\
\hline Group & Class I & Class II & Total \\
\hline 1 & 0 & 6 & 6 \\
2 & 3 & 3 & 6 \\
Total & 3 & 9 & 12 \\
& $\chi^{2}=\mathbf{4 . 0 0} ; \mathrm{GL}=1 ; \mathrm{p}=0.045^{*}$ & \\
\hline
\end{tabular}

*Statistically significant difference $(P<0.05)$.

Table 2 - Intergroup comparison of initial and final ages as well as treatment period (independent t tests).

\begin{tabular}{cccc}
\hline $\begin{array}{c}\text { Variables } \\
\text { (years) }\end{array}$ & $\begin{array}{c}\text { G1 Extraction of \#14 } \\
\text { and \#24 teeth }(\mathbf{n}=6)\end{array}$ & $\begin{array}{c}\text { G2 Without } \\
\text { extractions }(\mathbf{n}=6)\end{array}$ & $\mathbf{P}$ \\
\hline Initial age & $15.83 \pm 4.87$ & $18.26 \pm 6.42$ & 0.477 \\
\hline Final age & $18.36 \pm 4.84$ & $20.65 \pm 6.45$ & 0.502 \\
\hline $\begin{array}{c}\text { Treatment } \\
\text { period }\end{array}$ & $2.53 \pm 0.49$ & $2.39 \pm 0.66$ & 0.682 \\
\hline
\end{tabular}

Table 3 - Intergroup comparison of variables studied during the initial stage $\left(T_{1}\right)$ (independent $t$ tests).

\begin{tabular}{|c|c|c|c|}
\hline Variables & $\begin{array}{l}\text { C1 Extraction of } \\
\text { \#14 and \#24 teeth } \\
n=6\end{array}$ & $\begin{array}{c}\text { C2 Without } \\
\text { extraction } \\
n=6\end{array}$ & $\mathbf{p}$ \\
\hline & Mean \pm SD & Mean \pm SD & \\
\hline $\begin{array}{l}\text { Crown-root } \\
\text { ratio }(\mathrm{mm})\end{array}$ & $1.44 \pm 0.20$ & $1.52 \pm 0.16$ & 0.444 \\
\hline Length 11 (mm) & $24.92 \pm 1.91$ & $25.48 \pm 2.17$ & 0.643 \\
\hline 1-PTV incisal(mm) & $63.78 \pm 6.35$ & $55.65 \pm 6.65$ & 0.055 \\
\hline 1-PTV apical (mm) & $51.71 \pm 4.57$ & $36.66 \pm 5.04$ & $0.000^{*}$ \\
\hline FMA (degrees) & $23.81 \pm 5.11$ & $25.22 \pm 5.02$ & 0.640 \\
\hline PFH/AFH (mm) & $0.63 \pm 0.07$ & $0.70 \pm 0.06$ & 0.153 \\
\hline ANB (degrees) & $4.10 \pm 1.71$ & $3.29 \pm 2.98$ & 0.580 \\
\hline Wits (mm) & $-0.20 \pm 4.57$ & $-0.26 \pm 5.12$ & 0.982 \\
\hline 1.NA (degrees) & $27.96 \pm 10.67$ & $21.06 \pm 6.32$ & 0.202 \\
\hline $\mathrm{H}-11(\mathrm{~mm})$ & $20.51 \pm 1.98$ & $18.05 \pm 3.56$ & 0.169 \\
\hline$U A+U P(m m)$ & $18.11 \pm 8.95$ & $13.46 \pm 3.75$ & 0.267 \\
\hline UA cerv (mm) & $0.84 \pm 0.52$ & $0.67 \pm 0.41$ & 0.539 \\
\hline UP cerv (mm) & $1.68 \pm 0.91$ & $1.20 \pm 0.49$ & 0.283 \\
\hline UA middle (mm) & $0.61 \pm 0.28$ & $0.47 \pm 0.30$ & 0.398 \\
\hline UP middle (mm) & $2.77 \pm 1.64$ & $2.01 \pm 0.62$ & 0.315 \\
\hline UA apical (mm) & $1.31 \pm 0.84$ & $0.99 \pm 0.36$ & 0.408 \\
\hline UP apical (mm) & $4.24 \pm 2.45$ & $3.03 \pm 1.38$ & 0.318 \\
\hline
\end{tabular}

*Statistically significant difference $(P<0.05)$ 
Table 4 - Comparison between initial $\left(T_{1}\right)$ and final $\left(T_{2}\right)$ stages of group 1, with premolar extractions (dependent t tests).

\begin{tabular}{|c|c|c|c|c|}
\hline Variables & $\begin{array}{l}\text { Initial stage } \\
\left(T_{1}\right) n=6\end{array}$ & $\begin{array}{c}\text { Final stage } \\
\left(T_{2}\right) n=6\end{array}$ & $\begin{array}{c}\text { Changes } \\
T_{2}-T_{1}\end{array}$ & $\mathbf{p}$ \\
\hline & Mean \pm SD & Mean \pm SD & & \\
\hline $\begin{array}{l}\text { Crown-root } \\
\text { ratio (mm) }\end{array}$ & $1: 1.44 \pm 0.20$ & $1: 1.32 \pm 0.25$ & -0.12 & $0.009 *$ \\
\hline Length. 11 (mm) & $24.92 \pm 1.91$ & $23.65 \pm 2.12$ & -1.27 & $0.013^{*}$ \\
\hline 1-PTV incisal (mm) & $63.78 \pm 6.35$ & $52.45 \pm 4.18$ & -11.33 & $0.003^{\star}$ \\
\hline 1-PTV apical (mm) & $51.71 \pm 4.57$ & $43.30 \pm 5.17$ & -8.41 & $0.013^{*}$ \\
\hline FMA (degrees) & $23.81 \pm 5.11$ & $23.28 \pm 5.13$ & -0.53 & 0.458 \\
\hline PFH/AFH (mm) & $0.63 \pm 0.07$ & $0.64 \pm 0.08$ & 0.01 & 0.258 \\
\hline ANB (degrees) & $4.10 \pm 1.71$ & $2.61 \pm 1.38$ & -1.49 & $0.006^{*}$ \\
\hline Wits (mm) & $-0.20 \pm 4.57$ & $-0.50 \pm 5.05$ & -0.30 & 0.752 \\
\hline 1.NA (degrees) & $27.96 \pm 10.67$ & $20.99 \pm 4.08$ & -6.97 & 0.136 \\
\hline $\mathrm{H}-11(\mathrm{~mm})$ & $20.51 \pm 1.98$ & $19.09 \pm 2.09$ & -1.42 & 0.399 \\
\hline$\cup A+U P(m m)$ & $18.11 \pm 8.95$ & $13.53 \pm 3.18$ & -4.58 & 0.133 \\
\hline UA cerv (mm) & $0.84 \pm 0.52$ & $1.48 \pm 0.40$ & 0.64 & $0.025^{\star}$ \\
\hline UP cerv (mm) & $1.68 \pm 0.91$ & $0.28 \pm 0.69$ & -1.40 & $0.001^{*}$ \\
\hline UA middle $(\mathrm{mm})$ & $0.61 \pm 0.28$ & $1.77 \pm 1.43$ & 1.16 & 0.077 \\
\hline UP middle (mm) & $2.77 \pm 1.64$ & $1.15 \pm 0.96$ & -1.62 & $0.005^{\star}$ \\
\hline UA apical (mm) & $1.31 \pm 0.84$ & $3.27 \pm 3.44$ & 1.96 & 0.170 \\
\hline UP apical (mm) & $4.24 \pm 2.45$ & $2.69 \pm 2.09$ & -1.55 & 0.200 \\
\hline
\end{tabular}

*Statistically significant difference $(P<0.05)$.

Table 6 - Intergroup comparison of the studied variables at the final stage $\left(T_{2}\right)$ (independent $t$ tests).

\begin{tabular}{|c|c|c|c|}
\hline Variables & $\begin{array}{l}\text { G1 Extraction of } \\
\begin{array}{l}\text { \#14 and \#24 teeth } \\
n=6\end{array}\end{array}$ & $\begin{array}{c}\text { G2 Without } \\
\text { extraction } \\
\quad n=6\end{array}$ & $\mathbf{p}$ \\
\hline & Mean \pm SD & Mean \pm SD & \\
\hline $\begin{array}{l}\text { Crown-root } \\
\text { ratio }(\mathrm{mm})\end{array}$ & $1.32 \pm 0.25$ & $1.43 \pm 0.14$ & 0.343 \\
\hline Length 11 (mm) & $23.65 \pm 2.12$ & $24.59 \pm 1.86$ & 0.434 \\
\hline 1-PTV incisal (mm) & $52.45 \pm 4.18$ & $63.26 \pm 6.00$ & $0.004^{*}$ \\
\hline 1-PTV apical (mm) & $43.30 \pm 5.17$ & $41.80 \pm 4.04$ & 0.586 \\
\hline FMA (degrees) & $23.28 \pm 5.13$ & $23.16 \pm 4.60$ & 0.968 \\
\hline $\mathrm{PFH} / \mathrm{AFH}(\mathrm{mm})$ & $0.64 \pm 0.08$ & $0.72 \pm 0.07$ & 0.133 \\
\hline ANB (degrees) & $2.61 \pm 1.38$ & $2.82 \pm 2.34$ & 0.855 \\
\hline Wits (mm) & $-0.50 \pm 5.05$ & $-0.28 \pm 5.51$ & 0.944 \\
\hline 1.NA (degrees) & $20.99 \pm 4.08$ & $24.63 \pm 6.61$ & 0.277 \\
\hline $\mathrm{H}-11(\mathrm{~mm})$ & $19.09 \pm 2.09$ & $19.90 \pm 3.27$ & 0.621 \\
\hline$\cup A+U P(m m)$ & $13.53 \pm 3.18$ & $14.35 \pm 4.89$ & 0.738 \\
\hline UA cerv (mm) & $1.48 \pm 0.40$ & $0.61 \pm 0.57$ & $0.012^{*}$ \\
\hline UP cerv (mm) & $0.28 \pm 0.69$ & $0.53 \pm 0.59$ & 0.515 \\
\hline UA middle (mm) & $1.77 \pm 1.43$ & $0.63 \pm 0.61$ & 0.103 \\
\hline UP middle (mm) & $1.15 \pm 0.96$ & $1.21 \pm 0.81$ & 0.907 \\
\hline UA apical (mm) & $3.27 \pm 3.44$ & $0.99 \pm 0.78$ & 0.146 \\
\hline UP apical (mm) & $2.69 \pm 2.09$ & $2.47 \pm 1.28$ & 0.828 \\
\hline
\end{tabular}

*Statistically significant difference $(P<0.05)$
Table 5 - Comparison between initial $\left(T_{1}\right)$ and final $\left(T_{2}\right)$ stages of group 2 without extractions (dependent $t$ tests)

\begin{tabular}{|c|c|c|c|c|}
\hline Variables & $\begin{array}{l}\text { Initial stage } \\
\left(T_{1}\right) n=6\end{array}$ & $\begin{array}{l}\text { Final stage } \\
\left(T_{2}\right) n=6\end{array}$ & $\begin{array}{c}\text { Changes } \\
T_{2}-T_{1}\end{array}$ & $\mathbf{p}$ \\
\hline & Mean \pm SD & Mean \pm SD & & \\
\hline $\begin{array}{l}\text { Crown-root } \\
\text { ratio (mm) }\end{array}$ & $1.52 \pm 0.16$ & $1.43 \pm 0.14$ & -0.09 & $0.013^{*}$ \\
\hline Length 11 (mm) & $25.48 \pm 2.17$ & $24.59 \pm 1.86$ & -0.89 & $0.005^{\star}$ \\
\hline 1-PTV incisal (mm) & $55.65 \pm 6.65$ & $63.26 \pm 6.00$ & 7.61 & 0.142 \\
\hline 1-PTV apical (mm) & $36.66 \pm 5.04$ & $41.80 \pm 4.04$ & 5.14 & 0.138 \\
\hline FMA (degrees) & $25.22 \pm 5.02$ & $23.16 \pm 4.60$ & -2.06 & $0.015^{\star}$ \\
\hline $\mathrm{PFH} / \mathrm{AFH}(\mathrm{mm})$ & $0.70 \pm 0.06$ & $0.72 \pm 0.07$ & 0.02 & $0.034^{*}$ \\
\hline ANB (degrees) & $3.29 \pm 2.98$ & $2.82 \pm 2.34$ & -0.47 & 0.482 \\
\hline Wits (mm) & $-0.26 \pm 5.12$ & $-0.28 \pm 5.51$ & 0.02 & 0.986 \\
\hline 1.NA (degrees) & $21.06 \pm 6.32$ & $24.63 \pm 6.61$ & 3.57 & $0.007^{*}$ \\
\hline $\mathrm{H}-11(\mathrm{~mm})$ & $18.05 \pm 3.56$ & $19.90 \pm 3.27$ & 1.85 & 0.267 \\
\hline$\cup A+\cup P(m m)$ & $13.46 \pm 3.75$ & $14.35 \pm 4.89$ & 0.89 & 0.662 \\
\hline UA cerv (mm) & $0.67 \pm 0.41$ & $0.61 \pm 0.57$ & -0.06 & 0.762 \\
\hline UP cerv (mm) & $1.20 \pm 0.49$ & $0.53 \pm 0.59$ & -0.67 & 0.132 \\
\hline UA middle $(\mathrm{mm})$ & $0.47 \pm 0.30$ & $0.63 \pm 0.61$ & 0.16 & 0.658 \\
\hline UP middle (mm) & $2.01 \pm 0.62$ & $1.21 \pm 0.81$ & -0.80 & $0.049 *$ \\
\hline UA apical (mm) & $0.99 \pm 0.36$ & $0.99 \pm 0.78$ & 0.00 & 0.995 \\
\hline UP apical (mm) & $3.03 \pm 1.38$ & $2.47 \pm 1.28$ & -0.56 & 0.406 \\
\hline
\end{tabular}

*Statistically significant difference $(P<0.05)$

Table 7 - Intergroup comparison of the studied variables concerning treatment changes $\left(T_{2}-T_{1}\right)$ (independent t tests).

\begin{tabular}{|c|c|c|c|}
\hline Variables & $\begin{array}{l}\text { G1 Extraction of } \\
\begin{array}{l}\text { \#14 and \#24 teeth } \\
n=6\end{array}\end{array}$ & $\begin{array}{l}\text { G2 Without } \\
\text { extraction } \\
\quad n=6\end{array}$ & $\mathbf{p}$ \\
\hline & Mean \pm SD & Mean \pm SD & \\
\hline $\begin{array}{l}\text { Crown-root } \\
\text { ratio }(\mathrm{mm})\end{array}$ & $-0.12 \pm 0.07$ & $-0.08 \pm 0.05$ & 0.402 \\
\hline Length 11 (mm) & $-1.26 \pm 0.82$ & $-0.89 \pm 0.46$ & 0.359 \\
\hline 1-PTV incisal (mm) & $-11.33 \pm 5.44$ & $7.61 \pm 10.73$ & $0.003^{*}$ \\
\hline 1-PTV apical (mm) & $-8.40 \pm 5.48$ & $5.13 \pm 7.15$ & $0.004^{*}$ \\
\hline FMA (degrees) & $-0.53 \pm 1.62$ & $-2.05 \pm 1.40$ & 0.113 \\
\hline $\mathrm{PFH} / \mathrm{AFH}(\mathrm{mm})$ & $0.00 \pm 0.01$ & $0.02 \pm 0.01$ & 0.209 \\
\hline ANB (degrees) & $-1.48 \pm 0.82$ & $-0.47 \pm 1.52$ & 0.182 \\
\hline Wits (mm) & $-0.29 \pm 2.18$ & $-0.01 \pm 2.23$ & 0.830 \\
\hline 1.NA (degrees) & $-6.97 \pm 9.62$ & $3.57 \pm 2.04$ & $0.025^{*}$ \\
\hline $\mathrm{H}-11(\mathrm{~mm})$ & $-1.42 \pm 3.79$ & $1.85 \pm 3.63$ & 0.157 \\
\hline$\cup A+U P(m m)$ & $-4.58 \pm 6.27$ & $0.88 \pm 4.66$ & 0.117 \\
\hline UA cerv (mm) & $0.63 \pm 0.49$ & $-0.06 \pm 0.47$ & $0.031 *$ \\
\hline UP cerv (mm) & $-1.39 \pm 0.51$ & $-0.66 \pm 0.90$ & 0.113 \\
\hline UA middle (mm) & $1.15 \pm 1.27$ & $0.16 \pm 0.86$ & 0.145 \\
\hline UP middle (mm) & $-1.62 \pm 0.86$ & $-0.80 \pm 0.76$ & 0.111 \\
\hline UA apical (mm) & $1.95 \pm 2.98$ & $0.00 \pm 0.74$ & 0.151 \\
\hline UP apical (mm) & $-1.54 \pm 2.57$ & $-0.56 \pm 1.51$ & 0.436 \\
\hline
\end{tabular}

*Statistically significant difference $(P<0.05)$ 


\begin{tabular}{|c|c|c|c|}
\hline Variable & $\begin{array}{l}\text { G1 Extractions of \#14 } \\
\begin{array}{c}\text { and } \# 24 \text { teeth } \\
n=6\end{array}\end{array}$ & $\begin{array}{c}\text { G2 } \\
\text { Without extractions } \\
n=6\end{array}$ & $\mathbf{p}$ \\
\hline & Mean \pm SD & Mean \pm SD & \\
\hline ERR $T_{1}$ & $0,16 \pm 0,40$ & $0,16 \pm 0,40$ & 1,000 \\
\hline$E R R T_{2}$ & $1,50 \pm 1,04$ & $1,00 \pm 0,00$ & 0,336 \\
\hline ERR $T_{2-1}$ & $1,33 \pm 0,81$ & $0,83 \pm 0,40$ & 0,240 \\
\hline
\end{tabular}

the occurrence of unfavorable sequelae to orthodontic movement, especially fenestration, bone dehiscence and root resorption. This information can influence the patient's treatment planning which, prior to orthodontic treatment, can be diagnosed as unfavorable to great teeth movement. The tridimensional analysis provided by computed tomography is of great importance for an accurate assessment of craniofacial morphology because through this examination, it is possible to obtain more reliable information on the dimensions and levels of facial bone tissues when compared to traditional bidimensional examinations. Moreover, CT is considered as a noninvasive, fast, high-accurate diagnosis method., ${ }^{72,13}$

It is important to underline the difficulty and the merit of obtaining a sample comprising 12 patients not only examined with lateral cephalograms, computed tomographies and periapical radiographs at the beginning of the treatment and after 18 months, but also who meet the aforementioned inclusion criteria of this study methodology. As the study was accomplished using $\mathrm{CT}$, which is difficult to be obtained due to the cost and the ethical question concerning radiation exposure, the sample of 12 patients, is considered acceptable.

\section{Methods}

Measurements were performed on the maxillary central incisor because this is the tooth that shows more resorption during orthodontic movement. ${ }^{14,15}$ Periapical radiograph was the examination chosen to evaluate root resorption because it presents less distortion and more details when compared to panoramic radiograph and lateral cephalograms. ${ }^{11}$

Lateral cephalograms were used to obtain standard cephalometric measurements as well as to measure the alveolar thickness at the apical area of the right maxillary central incisor from a linear distance traced parallel to the palatal plane extending from labial to palatal cortical plate. ${ }^{5}$
Computed tomography was performed by two different radiology centers, by the same examiner in each one of them. CTs were obtained during $\mathrm{T}_{1}$ (the beginning of the orthodontic treatment) and $\mathrm{T}_{2}$ (after tooth extraction space closure). CT scans were used to evaluate bone thickness at the cervical, middle and apical thirds of the root of the right maxillary central incisor, tracing three lines parallel to the ECJ plane at a $3 \mathrm{~mm}$ interval. These measurements aimed to identify lack of bone tissue which may indicate fenestration or bone dehiscence. Fenestration is the lack of bone tissue in a restricted area of the tooth root ${ }^{16}$ while dehiscence occurs when the lack of bone involves the alveolar bone ridge. ${ }^{16}$

\section{Results}

The results demonstrate that there was no difference between genders, i.e., the intergroup comparison showed compatibility regarding the number of males and females in each group. Additionally, there was no difference concerning the variables "age" and "treatment period". Considering the variable "malocclusion type", the samples were not compatible at the beginning of the treatment. G1 exhibited 3 patients with Class II malocclusion which did not influence the results of this study because the objective was to evaluate the changes in bone thickness at incisors area during the retraction of the anterior teeth, i.e., the importance was in performing or not the retraction of the anterior teeth regardless of the malocclusion type.

Regarding the variables studied during $\mathrm{T}_{1}$, only 1-PTV demonstrated statistically significant difference. This occurred because G2 presented less protrusion of maxillary anterior teeth when compared to G1. This result was already expected, since great dentoalveolar protrusion of G1 patients probably influenced the decision to perform teeth extraction in this group. Premolar extractions have been frequently employed aiming to reduce dentoalveolar protrusion. ${ }^{17}$

During treatment, G1 (with extractions) underwent changes in the crown-root ratio, maxillary incisor length, 1-PTV incisal, 1-PTV apical and in the maxillomandibular relationship. These changes were expected due to premolar extractions and space closure caused by retraction of the maxillary anterior teeth. ${ }^{18}$ Alveolar bone thickness at the labial cervical third (UL cervical) significantly increased. Bone thickness decreased at the palatal cervical and middle thirds (UP cervical and UP middle). 
As Handelman ${ }^{5}$ reported, tooth movement can alter the distance between alveolar cortical plates in relation to the roots of the orthodontically moved teeth, i.e., the anteroposterior movement of the incisors can lead to bone loss in the direction of the movement. ${ }^{19}$

The changes occurring in G2 (without extractions), during the treatment phase, were significant in the following variables: crown-root ratio, incisor length, FMA, PFH-AFH, 1.NA, and UP middle. Similarly to G1, there were significant root resorptions in the studied teeth due to tooth movement during treatment. ${ }^{20,21}$ The maxillary incisors presented significant vestibularization. This occurred for two main reasons: the incisors alignment that were slightly crowded and the Curve of Spee flatting during treatment.

At the final stage $\left(\mathrm{T}_{2}\right)$, the results of the studied variables indicated a statistically significant difference in two variables: 1-PTV incisal and UL cervical. At this stage, 1-PTV incisal of G2 was greater than 1-PTV incisal of G1, indicating that in G2, the maxillary central incisors were more protruded at the end of the treatment than those of G1. This occurred due to the sum of the statistically significant retraction (1-PTV incisal and 1-PTV apical) suffered by the incisors of G1 and the vestibularization (1.NA) suffered by the incisors of G2 during the treatment period (Tables 4 and 5). UL cervical also presented a statistically significant difference between Groups at $T_{2}$. The maxillary incisors of G1 presented a statistically significant decrease of the labial alveolar bone thickness at the cervical third in relation to the maxillary incisors of G2. This effect occurred because G1 (with extractions) underwent maxillary incisors retraction during treatment and G2 (without extractions) presented only vestibularization of these teeth.

The intergroup comparison concerning the variables changes occurring as a result of the treatment (Table 7) demonstrates that 1-PTV incisal and 1-PTV apical exhibited statistically significant differences. With regard to the 1-PTV incisal, the group with extractions presented a maxillary incisor retraction of $11.33 \mathrm{~mm}$ while the group without extractions presented a protraction of $7.61 \mathrm{~mm}$. In respect to 1-PTV apical, the group with extractions presented a maxillary incisor retraction of $8.40 \mathrm{~mm}$ while the group without extractions presented a protraction of $5.13 \mathrm{~mm}$. The sum of these changes resulted in the statistically differences showed by these variables in relation to these groups of study.
Such differences have already been proved by several previous studies comparing dentoskeletal changes between extraction and nonextraction cases. ${ }^{22,23,24}$

The inclination of the incisors evaluated by the variable 1.NA also underwent a statistically significant difference between groups. While in G1 the incisors showed a palatal change of $6.97^{\circ}$, in G2, without extractions, the incisors were vestibularized in $3.57^{\circ}$. This result was expected, since G1 presented retraction of maxillary incisors during the extraction space closure and G2 had these teeth vestibularized by the alignment and leveling of the teeth that presented mild crowding and overbite, as described above.

According to Lupi, Handelman and Sadowsky, ${ }^{25}$ both the treatment carried out with extractions and the amount of force used for orthodontic movement may influence alveolar bone loss. These authors also claim that bone dehiscence and fenestration have been reported when the incisors are protracted or retracted; maxillary incisor protraction produces a dehiscence in labial alveolar bone while its retraction affects the palatal alveolar ridge. ${ }^{25}$

The change in UL cervical also showed a significant difference between groups. In G1, labial bone thickness at the cervical area presented an increase of $0.67 \mathrm{~mm}$ while in $\mathrm{G} 2$ bone thickness decreased $0.06 \mathrm{~mm}$. These changes were also expected due to the same aforementioned reasons. The other variables analyzed on CT scans, aiming to assess the alveolar bone thickness at other root areas, did not undergo any significant changes between groups, therefore demonstrating strong evidence that the alveolar cortical plates could be submitted to re-anatomization, modifying their shape and position. ${ }^{2,26}$ These results do not agree with the hypothesis of Hadelman regarding the limitation of tooth movement by alveolar cortical plates, ${ }^{5}$ showing that alveolar bone remodeling is possible during tooth movement induced by biological forces. ${ }^{2,26}$

\section{External root resorption}

External root resorption is one of the consequences caused by orthodontic movement. This study evaluated the degree of external root resorption through the scores proposed by Levander and Malmgren in $1988 .{ }^{11}$ According to Cheng et $\mathrm{al}^{27}$ one of the biological factors influencing inflammatory root resorption during orthodontic movement is the root morphology, moreover, age, gender, metabolism velocity and tooth anomaly, 
factors which the clinician cannot control, also influence inflammatory root resorption during orthodontic movement. Factors related to the treatment are: amount of movement, treatment time and the magnitude of the applied force..$^{28,29}$

This study did not find statistically significant differences in root resorption between the groups, however, it is not advisable to affirm that these resorptions did not occur or were not clinically important. According to some authors, patients submitted to retraction of anterior teeth through lingual root torque presenting low bone thickness, i.e., small alveolar width, clinically demonstrate a decrease in alveolar bone thickness and a greater tendency towards external root resorption. ${ }^{2,30}$

\section{CONCLUSIONS}

There were no changes in alveolar bone thickness when extractions and nonextraction cases were compared, except for labial alveolar bone thickness at the cervical third of the maxillary incisors.
1. Krishnan V, Davidovitch Z. Cellular, molecular, and tissue-level reactions to orthodontic force. Am J Orthod Dentofacial Orthop. 2006;129(4):469-e1-32.

2. Vardimon AD, Oren E, Ben-Bassat Y. Cortical bone remodeling/tooth movement ratio during maxillary incisor retraction with tip versus torque movements. Am J Orthod Dentofacial Orthop. 1998:114(5):520-9

3. Artun J, Krogstad $\mathrm{O}$. Periodontal status of mandibular incisors following excessive proclination. A study in adults with surgically treated mandibular prognathism. Am J Orthod Dentofacial Orthop. 1987:91(3):225-32.

4. Yared KF, Zenobio EG, Pacheco W. Periodontal status of mandibular central incisors after orthodontic proclination in adults. Am J Orthod Dentofacial Orthop. 2006;130(1):6 e1-8.

5. Handelman CS. The anterior alveolus: its importance in limiting orthodontic treatment and its influence on the occurrence of iatrogenic sequelae. Angle Orthod. 1996:66(2):95-109; discussion 109-10.

6. Karring T, Nyman S, Thilander B, Magnusson I. Bone regeneration in orthodontically produced alveolar bone dehiscences. J Periodontal Res. 1982 May:17(3):309-15

7. Garcia R, Claro C, Chagas R, Almeida G. Espessura do processo alveolar da região anterior da maxila e mandibula em pacientes com discrepância óssea ânteroposterior. Rev Dental Press Ortod Ortop Facial. 2005;10(5):137-48.

8. Kim HJ, Yun HS, Park HD, Kim DH, Park YC. Soft-tissue and cortical-bone thickness at orthodontic implant sites. Am J Orthod Dentofacial Orthop. 2006:130(2):177-82.

9. Capelozza Filho L, Fattori L, Maltagliati LA. Um novo método para avaliar as inclinações dentárias utilizando a tomografia computadorizada. Rev Dental Press Ortod Ortop Facial. 2005;10(5):23-9.

10. De Vos W, Casselman J, Swennen GR. Cone-beam computerized tomography (CBCT) imaging of the oral and maxillofacial region: a systematic review of the literature. Int J Oral Maxillofac Surg. 2009:38(6):609-25.

11. Levander $E$, Malmgren $O$. Evaluation of the risk of root resorption during orthodontic treatment: a study of upper incisors. Eur J Orthod. 1988;10(1):30-8.

12. Consolaro A. Tomografia volumétrica (Odontológica) versus helicoidal (Médica) no planejamento ortodôntico e no diagnóstico das reabsorções dentárias. Rev Clín Ortod Dental Press. 2007:6(4):108-11.

13. Rodrigues AF, Vitral RWF. Aplicações da tomografia computadorizada na Odontologia. Pesq Bras Odontoped Clín Integrada. 2007:7:317-24.

14. Parker RJ, Harris EF. Directions of orthodontic tooth movements associated with external apical root resorption of the maxillary central incisor. Am J Orthod Dentofacial Orthop. 1998;114(6):677-83.

15. Janson G, De Luca Canto G, Martins D, Henriques J, De Freitas M. A radiographic comparison of apical root resorption after orthodontic treatment with 3 different fixed appliance techniques. Am J Orthod Dentofacial Orthop. 2000;118(3):262-73.
16. Carranza F, Newman M, Takei H. Periodontia clínica. 9a ed. Rio de Janeiro Guanabara Koogan; 2002.

17. Baumrind S, Korn EL, Boyd RL, Maxwell R. The decision to extract: part II. Analysis of clinicians stated reasons for extraction. Am J Orthod Dentofacial Orthop. 1996;109(4):393-402.

18. Luppanapornlarp S, Johnston LE Jr. The effects of premolar-extraction: a longterm comparison of outcomes in "clear-cut" extraction and nonextraction Class II patients. Angle Orthod. 1993;63(4):257-72.

19. Wehrbein H, Bauer W, Diedrich P. Mandibular incisors, alveolar bone, and symphysis after orthodontic treatment. A retrospective study. Am J Orthod Dentofacial Orthop. 1996;110(3):239-46.

20. Consolaro A. Reabsorção dentária na movimentação ortodôntica. In: Reabsorções dentárias nas especialidades clínicas. 1a ed. Maringá: Dental Press; 2002. p. 259-89

21. Marques LS, Ramos-Jorge ML, Rey AC, Armond MC, Ruellas AC. Severe root resorption in orthodontic patients treated with the edgewise method: prevalence and predictive factors. Am J Orthod Dentofacial Orthop. 2010;137(3):384-8.

22. Basciftci FA, Usumez $\mathrm{S}$. Effects of extraction and nonextraction treatment on Class I and Class II subjects. Angle Orthod. 2003;73(1):36-42.

23. Kocadereli I. Changes in soft tissue profile after orthodontic treatment with and without extractions. Am J Orthod Dentofacial Orthop. 2002;122(1):67-72.

24. Rains MD, Nanda R. Soft-tissue changes associated with maxillary incisor retraction. Am J Orthod. 1982;81(6):481-8.

25. Lupi JE, Handelman CS, Sadowsky C. Prevalence and severity of apical root resorption and alveolar bone loss in orthodontically treated adults. Am J Orthod Dentofacial Orthop. 1996;109(1):28-37.

26. Meikle MC. The dentomaxillary complex and overjet correction in Class II, division 1 malocclusion: objectives of skeletal and alveolar remodeling. Am J Orthod. 1980;77(2):184-97.

27. Cheng LL, Turk T, Elekdag-Turk S, Jones AS, Petocz P, Darendeliler MA. Physical properties of root cementum: Part 13. Repair of root resorption 4 and 8 weeks after the application of continuous light and heavy forces for 4 weeks: a microcomputed-tomography study. Am J Orthod Dentofacial Orthop. 2009:136(3):320 e1-10; discussion -1.

28. Brezniak N, Wasserstein A. Orthodontically induced inflammatory root resorption Part I: The basic science aspects. Angle Orthod. 2002;72(2):175-9.

29. Mirabella AD, Artun J. Risk factors for apical root resorption of maxillary anterior teeth in adult orthodontic patients. Am J Orthod Dentofacial Orthop. 1995;108(1):48-55

30. Horiuchi A, Hotokezaka H, Kobayashi K. Correlation between cortical plate proximity and apical root resorption. Am J Orthod Dentofacial Orthop. 1998;114(3):311-8. 